\title{
USE OF THE INDETERMINATE SENTENCE IN CRIME PREVENTION AND REHABILITATION
}

\author{
THE philosophy that originally underlay the science of penology is \\ clearly indicated by the fact that the treatment of criminal offenders \\ is, even today, still widely characterized as "punishment"-connoting \\ the exaction of a penalty primarily, if not exclusively, in retribution for \\ the offense committed. ${ }^{1}$ There has developed in more recent times,
}

\footnotetext{
2 This largely inaccurate usage of the word "punishment" betrays the agonized development of the science of penology. Although countless authors and numerous socalled theories have contributed to the heritage of contemporary criminology, perhaps the Neo-Classic and Italian theories have enjoyed the greatest following. SALEILLES, The Individualization of Punishment (IgII), is an extremely thorough and scholarly treatment of this historical development in penology. ULLMAN, THE MEDIEVAL IDEA OF LAW (1946), provides an equally learned insight into an earlier period. Beccaria, Bentham, and Fuerbach were prominent contributors to the eighteenth century Classic theory, the fundamental basis of which was to prescribe for each crime a sanction which theoretically outweighed the temptation to commit it, such sanction to be imposed objectively without regard to the personality of the offender. This principle was interpreted by Beccaria to mean that punishment should be based upon the seriousness of the offense, regardless of who committed it, but also should be prompt, certain, and as lenient as possible consistent with the protection of the community. Bogen, "Justice" v. "Individualived Treatment" in the Juvenile Court, 35 J. CRIM. L., C. \& P.S. 249 (1944). For interesting biographical sketches, see Geis, Pioneers in CriminologyBentham, 46 J. CRIM. L., C. \& P.S. 159 (1955) and Monachesi, Pioneers in Criminology-Beccaria, 46 J. CRIM. L., "C. \& P.S. 439 (1955). From this rigid concept, there sprang the Neo-Classic theory, which was distinguishable by its tempering recognition of the doctrines of responsibility and mitigation. Seizing upon this tendency towards individualization of "punishment," the Italian theory, born late in the nineteenth century, sought to extirpate any remaining predisposition exclusively to consider the crime. Lombrosi, the most renowned exponent of this "new" theory, mamtained that each crime is the inevitable issue of pathological temperament and that the disposition of each offender should reflect the measure of his evil potentiality only. That is, reformation should be the purpose of the courts, and the imposition of confinement, or other sanction, and its duration should depend upon a determination as to whether reformation is deemed unnecessary, necessary and attainable, or necessary but unattainable. In general, see Lombroso, Crime, Its Causes and ReMEdies (igir).

The impact of the Neo-Classic and Italian theories is clearly discernible in the impairment and virtual demise of the notion that retributive ineasures are adequate to the task of preventing repeated crime. For although punishment unquestionably was once the sole end of criminal justice, it is now relegated to a vastly inferior role. WArTE, The Prevention of Repeated Crime 9 (1943).

Reflecting principally the Classic theory is another prominent justification for the imposition of criminal sanctions-deterrence-the theory being that the imposition of a specific penalty alone will effectively dissuade the person punished as well as
} 
however, a more constructive conception of the role of incarcration, which is perhaps most concisely described as the protection of society. ${ }^{2}$

others from repetition in the same type of crime. This rationalization dies hard, even though experience has indicated rather clearly that it is quite invalid as the sole basis of crime prevention. Id. at 18-26. Nevertheless, this rationale is widely reflected in criminal legislation and is accorded some respect in all but the most advanced penological concepts. Sheer force of reason, unsupported by statistieal research, would seem to lead to the conclusion that the threat of formal condemnation of conviction, coupled with potential loss of liberty and independence must have some quantity of infuence upon behavior. Wechsler, Correctional Practices and the Law, I7 FED. Pro. 16 (March 1953). See also Bogen, supra at 25; Barksdale, J., Punishment for Crime, 19 FED. PRo. 5 (Sept. 1955). A veritable profusion of learned works now asserts that reformation of the criminal rather than deterrence by example is a better means of attaining the objective of crime prevention. SUthirrland, Princlples of CrimINOLOGY 340 (1924); WAITE, op. cit. supra at 28-32; AMERICAN PRISON Association, HandBook in Classification in CORRECTIONAL Institutions (1947); Reed, The Federal Youth Corrections Act in Operation, I8 FED. Pro. 1o (Sept. 1954); Yankwich, J., Individualization of Punishment in the Federal Courts, 2 I FED. Pro. 3 (March I957); Frym, The Treatment of Recidivists, 47 J. CRIM. L., C. \& P.S. I (1956).

Historical precedent indicates that a new means of fulfilling the purpose of the protection of society from the outrages of crime will be attempted if existing practices have proved ineffective. Therefore, proceeding from an assumption that the traditional statutory provisions have been found unequal to the task of preventing repeated crime, it is not surprising to note that there has been a prolonged search for a more perfect solution. More than twenty-five years ago a national committee concluded ". . . that the present prison system is antiquated and inefficient. It does not reform the criminal. It fails to protect society." 193 I Report of the National Committee on Law Observance and Enforcement, cited in Ellingston, The Youth Authority Program, in ConTEMPORARY Correction 125 (Tappan ed. I95I). See also Lewis, The Offender 115 (1917); note 7 infra. Nor is it a surprising social and economic fact that the achievements of criminologists and penologists have outstripped the creation of prison facilities and enactment of statutes. However, many states have enacted at least part of a program which would qualify as refornative, the realm of which measures is practically unlimited. It is believed that the following material offers a reasonable indication of many of the more important trends in the correctional field.

The federal prison system, which is entrusted to the Bureau of Prisons under the direction of the Attorney General of the United States, can serve well as the backdrop from which to illustrate the practices of other jurisdictions. 62 STAT. 849 (1948), 18 U.S.C.A. $\$ \S 4041-4042$ (195I). By federal legislation Congress has evinced a policy that federal institutions be so planned as to facilitate the developnent of an integrated correctional system which will assure the proper classiflcation and segregation of federal prisoners according to those factors which should be considered in providing individualized care and disciplime of prisoners. 62 STAT. 850 (1948), I8 U.S.C.A. $\S 4081$ (195I). In practice each of the approximately 25 institutions which make up the federal system has been specialized to provide a prograin attuned to the needs of one group of ten possible classifications of prisoners. Bennett, The Federal Prison System, in CONTEMPORARY CORRECTJON 63, 67, 7 I (Tappan ed. I95I).

The classification process is a basic administrative device, which implies both a thorough analysis of the individual and the factors in his past and environment and "... the organization of personnel and procedures through which the rehabilitative 
facilities of the institution may be directed most effectively toward a solution of the problems presented by the individual." American Prison Association, op. cit. supra note I, at I-3.

A refinement of classification is the reception center, a central study aud diagnostic unit to which convicted offenders are committed for classification and determination of their treatment program and the institution to which they should be transferred. At least seven states now have reception centers in operation as part of a state-adapted Youth Authority plan and/or for adults. They are: California, Massachusetts, Minnesota, New Jersey, New York, Pennsylvania and Wisconsin. Kendall, Reception Centers, in Contemporary Correction 107 (Tappan ed. 1951). Federal legisiation also removes the power of the conrts to commit offenders to a specific institution by placing this power and discretion to transfer prisoners from one institution to another with the Attorney General or his authorized representative. 62 STAT. 850 (1948), I8 U.S.C.A. $\$ 4082$ (1951).

The proposed Federal Corrections Act would remove an additional function of judges by granting to an Adult Correction Authority or a parole board the power to fix the sentence of an offender convicted of a felony after a study and classification of him has been completed. However, under the federal plan, the sentence so fixed must be approved by the judge before whoin the offender was convicted. Although California has enacted an Adult Authority plan, without the last named requirement, there is little enthusiasm for these reforms in other states. CAL. PENAL Code $\$ \S 5075-5082$ (Supp. 1957); Ploscowe, The Court and the Correctional System, in ConTemporary CorRECTION 51, 58, 59 (Tappan ed. 1951). Contra, Van Buren Perry, J., Federal In determinate Senterte, 32 J. CRIM. L., C. \& P.S. 397 (I94I).

Another plan for correcting and decreasing disparities in sentencing practices is the proposal for appellate examination of criminal sentences recommended by the American Law Institute and permitted in a limited manner in about seven states. Ploscowe, supra at 58. But see Barksdale, J., supra note 1 , at 8.

Once the offender has been fitted into a refornutive program, several treatment approaches are available within the correctional institution. For example, the administrators of these institutions can find a source of great assistance in the management of correctional cases by considering medical and psychological findings, by cooperating with the social worker, and by granting the chaplain access to inmates. Fuller, Medical Services, in Contemporary Correction 172 (Tappan ed. 1951); Brancale, Psychiatric and Psychological Services, in CONTEMPORARY CORRECTION rgr (Tappan ed. 1951); Pray, Social Work in the Prison Program, in Contemporary Correction 204 (Tappan ed. 1951); Kuether, Religion and the Chaplain, in CONTEMPORARY CORRECTION 254 (Tappan ed. 1951).

Case work aims at helping the individual acquire the capacity to make his own way to an adjustment of his activities in accordance with accepted standards of normal social living. Some workers contend that case work cannot function in an authoritarian setting because the client must seek help voluntarily and have free choice to terninate the relationship. Other students of the subject assert that to use authority wisely is essential so that the client can accept realities and learn that there are inviolable limits of social living. Pigeon, Principles and Methods in Dealing With Offenders 220 (1944); Chappell, Case Work, in Contemporary Correction 384, 386, 387 (Tappan ed. 1951 ).

A recent development is guided group interaction, the use of free discussion at group sessions "... to reeducate the delmquent to accept the restrictions of society and to find satisfaction in conforming to social norms." The New Jersey Department of 
Institutions and Agencies is experimenting with the application of this technique to reformatory populations. McCorkle, Group Therapy, in Contemporary CorRection 211, 215 (Tappan ed. 1951).

A broad, well-rounded program of education is a contributing force to a complete program of rehabilitation. In New York State and in the federal system arrangements are made with state education departunents to enable inmates to gain credits leading to high-school graduation and college-entrance diplomas. The unique California program has a staff of public-school teachers. Newer developments are also to be found in Illinois, Michigan, Minnesota, New Jersey, and Wisconsin. Bennett, supra at 72, 733 Chenault, Education, in CONTEMPORARY CORRECTION 224, 225, 230, 237 (Tappan ed. 1951).

A prison employment program can contribute not only to rehabilitation goals, such as instruction in specific trades so that men will learn to work under conditions which provide a real transfer value to civilian life, but can reduce the cost of correctional institutions to the taxpayers. In 1934 Congress created Federal Prison Industries, Inc., the industrial division of the Bureau of Prisons. The corporation now operates a diversified system of 42 industries in 18 institutions and employs about 3,200 inmates. Among the industries are a textile mill, shoe factory, metal furmiture factory, and an airplane mechanic school. The latter is a C.A.A. certified school for aircraft engine mechanics and a repair station for aircraft. The progress of the federal prisons must be contrasted with the absence of rational employment plans in the vast majority of the states. Two important difficulties prevent a quick solution of the employment problem. Public opinion is hostile toward prison-made goods and the only market for prison production is the government system-that is, state use and public works and ways. The Congressional Act of October 14, 1940, prohibited the interstate transportation of virtually all prison products with the exception of agricultural commodities and goods produced for states and their political subdivisions. Act of June 23, 1934, C. 736, $8 \S$ 1, 2, 48 STAT. 1211; 62 STAT. 851 (1948), I8 U.S.C.A. \$\$ 4121-4124 (1951); Bennett, supra at 73 ; Flynn, Employment and Labor, in CoNTEMPORARY CORRECTION 238, 239, 242, 244, 249, 250 (Tappan ed. 195I).

The characteristics of the institution itself present an area of correctional experimentation. "Both administrative attitudes and inmate response are deeply conditioned by the physical surroundings within which administrators operate and inmates live their lives." From the economy angle, taxpayers can be saved millions of dollars by building maximnm-custody institutions to house only those hardened criminals who must be securely confined and by retaining less dangerous prisoners in medium and minimum security institutions often costing half as much per inmate to build. From the security perspective, escape figures of the Federal Bureau of Prisons show that after the classification and segregation program was established the average yearly escapees per thousand prisoners was only $3.7,5.1$ prisoners less than before the program began. Barnes, Modern Prison Planning, in Contemporary Correction 269, 274 (Tappan ed. 1951 ).

Two significant noninstitutional inethods of treatment are probation and parole. Probation is supervision of the offender, imposed by the court, which takes place as a substitute for incarceration and never follows it. Parole is the release of an offender under supervision granted by an executive or an executive agency only after the prisoner has served a portion of his sentence. In many states and in the federal system the supervision of parolees and probationers is combined under the same administrative organization. Today all states have parole laws of some type. While no state is without some statutory provision for probation for minors, three states have no legal pro- 
visions for probation of adult offenders. It is estimated that $1 / 3$ of the population of the nation is without any probation service and that for another $1 / 8$ of the population probation is serionsly handicapped. Killinger, Parole and Other Release Procedures, in CONTEMPORARY CoRrection 361-363 (Tappan ed. 1951); Turnbladh, Cutrent Status of Probation, in Contemporary Correction 394 (Tappan ed. 195I); Richardson, Chairman, U.S. Board of Parole, Policies and Procedures of the U.S. Board of Parole, 19 FED. Pro. 14 (Dec. 1955).

Using' the criterion of convictions, the postprobation recidivisin rate of federal prisoners revealed by one test was only $17.7 \%$ of the group. England, $A$ Study of Postprobation Recidivism Among 500 Federal Offenders, I9 FED. PRo. 10 (Sept. 1955). According to statistics released by George J. Reed, Chairman, U.S. Board of Parole, there was an $80 \%$ success rate for all federal prisoners granted parole in the fiscal year of 1956-1957. That there is a substantial economic value in the use of parole is apparent from the fact that it costs an average of $\$ 1,394.30$ to house and care for one prisoner in an institution compared to a cost of $\$ 150.74$ a year to supervise him on parole. New York Times, December 27, 1957, p. 22, col. 1.

An administrative agency which coordinates all resources and activities within a correctional institution with those of the Division of Parole is the Service Unit. Since the inauguration of the Service Unit at Wallkill Prison in New York, this administrative tool has spread through its correctional system and is being copied in other states and in foreign countries. The objective of concentrating and coordimating total resources is likewise a goal of the federal system, which has a sound framework for the development of a closely integrated program with cooperation among the probation, parole, and institntional services. Wallack, The Service Unit, in CONTEMPORARY CORRECTION 141-143, 145 (Tappan ed. 1951); Loveland, Continuity in the Treatment of Offenders, 20 FED. PRO. 14, 15 (March 1956).

The final administrative device to be mentioned is the Youth Authority program, through which treatment tools may be fitted to the needs of adolescent offenders. This program is a response to the failure of traditional correctional machinery to rescue the youthful offender from a criminal career. There is good anthority for the claim that no less than $60 \%$ of the crime bill in the United States is created by uncorrected juvenile delinquents and that these criminals comprise the most serious offender group. Ellingston, The Youth Authority Program, in CoNTEMPORARY CORRECT1ON 124, 126 (Tappan ed. 2951); Loveland, supra at 15. And see Bobo, Juvenile Delinquency in the United States, 20 FED. PRO. 32 (June 1956). The Youth Authority has been adapted to the needs of five states since California first enacted such legislation in 1941. These states, California, Massachusetts, Minnesota, Texas, and Wisconsin all require that the new state agency take responsibility for all youth offenders committed to the state facilities. Arizona, Kentucky, and Washington have moved to create similar programs. This technique was introduced into the federal prison system by the 8 zst Congress in 1950 ; but for practical purposes it did not become effective until January 19, 1954. It has been available to all the district courts since October, 1956. The federal act also establishes a central agency, the Youth Correction Division of the Federal Board of Parole. . The act does not interfere with the power of the judge to sentence, but gives him an alternative method of treatment. 64 STAT. 1085 (1950), 18 U.S.C. $\$ \S 5005-5024$ (195I); Ellingston, supra at 126; Tappan, The Youth Authority Controversy, in Contemporary CoRrection 135 (Tappan ed. 1951); Breed, California Youth Authority Forestry Camp Program, 17 FED. Pro. 37 (June 1953); Reed, Chairman, Yonth Correction Division, The Federal Youth Corrections Act in Operation, I8 FED. Pro. Io (Sept. I954); Barksdale, J., supra note I, at 7, 8; Youngdahl, J., 
Particularly in combatting the immense problem of repeated crime, it has long and widely been recognized that individualized treatment ${ }^{3}$

infra note 5; Gottshall, Youth Corrections Act Sentencing Provisions, 21 FED. Pro. 57 (June 1957). Contra, Tappan, The Young Adult Offender Under the American Law Institute's Model Penal Code, 2o Fed. Pra. 32 (June 1956).

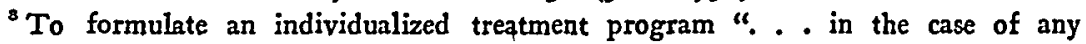
specific offender means first, to differentiate him from other offenders in personality, character, socio-economic background, the motivations of his crime, and his particular potentialities for reform or recidivism, and secondly to determine exactly which punitive, corrective, and medical measures are most adapted to solve the individualized set of problems presented by that offender in such a way that he will no longer commit crimes." Glueck, Pre-Sentence Examination, 41. J. CRIM. L., C. \& P.S. 717, 722 (1951). A quotation by Professor Vrij follows in the above article: "What audacity is involved in these three tasks: to interpret a life, explain an act, predict the slightest inclinations of a human mind." Glueck, supra at $72 \%, 723$.

Several American social scientists have been conducting investigations in an attempt to develop techniques which can satisfy the above demands of "individualization." It is hoped that recidivism can be prevented by suggesting, on the basis of empirical evidence, those treatment methods which will effect desirable modifications in the personality structure of offenders. See Monachesi, Amarican Studies in the Prediction of Recidivism, 41 J. CrIM. L., C. \& P.S. 268 (1950), for an article which summarizes the contrasting techniques employed to predict recidivipm and the outcome of treatment.

Dr. Sheldon Gueck, an outstanding student of prediction devices, directs attention to the variations between sentencing behaviors of judges, and suggests that, given a sufficient number of cases, one could expect that two judges would give sentences whose average severity would be about equal, provided the judges were influenced only by the circumstances of the crime and those of the prisoner. The Glueck prediction table is submitted as an instrument that will enable a judge to compare systematically the factors ascertained about an individual delinquent with 2 composite portrait of hundreds of other delinquents, in respect of charaoteristics previously demonstrated to be most nearly relevant to recidivism or reform, and thereby truly to individualize disposition of the particular offender through noting his similarities and differences in relation to "norms" and selecting the alternative dipposition most suited to this offender. A judge should not follow these tables blindly, but his training and experience can be "greatly aided" by considering relevant characteristics of the offender in the light of prediction tables. Glueck, supra at 723, 724, 73x; Glueck, The Sentencing Problem, 20 FED. Pro. 15, 17-19, 23, 24 (Dec. 1956).

The contention has been made that the impact of the views of Dr. Glueck is to relegate a presentence investigation of an offender to an auxiliary aid in support of a prediction table and to reject the role of a judge in any but a mechanical capacity, that sentencing becomes an arithmetical process, consisting of totaling points for only a few of the many dynamic factors making up the life of a defendant and adding a pinch or more of punishınent to suit pne's taste. It is feared that a prediction table would encourage a judge or parole bọard to look upon defendants or prisoners coldly and dehumanized. The argunent is presented that a judge, in sentencing, must consider not only the individual defendant, but the changing guality of the resources of his court, the probation department, the penal institutions, and the community. "The great limitation on the practicability of prediction tables is that they re rigid and mechanical in a setting that requires great fiexibility and judgment in a relationship witb human 
is the keystone to any progressive "sentencing plan"; and, consequently, it has been agreed that incarceration and its duration ideally should not depend upon arbitrary statutory prescription, but rather should remain within the discretion of competent authorities." It is not surprising, therefore, that all states, in varying degrees, have sought to realize this objective in fact by adopting some or all of the following sentencing devices: probation, parole, conditional release through good conduct, executive clemency, pardon, indefinite sentence with upper and lower limits, ${ }^{\sigma}$ indefinite sentence with only upper limit, and the indeterminate sentence-with neither upper nor lower limits. ${ }^{8}$ Of these, however, only

beings." Rubin, "Sentencing Goals: Real and Ideal," 21 FED. Pro. 51, 54-56 (June 1957).

Certainly, an accuracy in the prediction of behavior must be achieved far beyond that which is now achieved by informal and unsystematized methods, if such techniques are to be used in the administration of criminal justice. However, only a handful of studies have been made to test the efficiency of the available prediction tables and the results of these tests are conflicting and often discouraging. Monachesi, supra at $28 \mathrm{I}$, 282, 289. That some states which. do not use formal parole prediction factors have parole violation rates as low or even lower than a state which has established the prediction system, see Hartung, Book Review, 17 FED. Pro. 48 (March 1953).

Perhaps, the most encouraging findings are those which are accumulating. in support of the instruments presented by Sheldon and Eleanor Glueck. Even more definitive results may be derived in the not too distant future. Monachesi, supra at 283, 284; Thounpson, Further Validation of the Glueck Social Prediction Table for Identifying Potential Delinquents, 48 J. CRIM. L., C. \& P.S. 175, 176, 184 (1957).

* See the discussion of contemporary trends in the correctional field set forth in note 2 supra. See also note 6 infra in regard to the duration of confinement.

"This device, often referred to as "the indeterminate sentence" is enjoying a certain resurgence of popularity. Tappan, The Young Adult Offender Under the American Law Institute's Model Penal Code, I9 FED. Pro. 20 (Dec. 1955). But as to the advisability of having a fixed upper limit to a sentence, consider the following: "There is a serious insufficiency in this type of legislation, however, in that it does require eventual release of every convict no matter how imcoinpatible with public safety that release may be." WAITE, op. cit. supra note $x$, at 58 . There is equivalent objection to the imposition of a fixed ininimum sentencing linit. Youngdahl, J., Give the Youth Correction Program a Chance, 20 FED. Pro. 3, 6 (March 1956); Rubin, supra note 3, at 23.

-WAITE, op. cit. supra note 1 , at 89. In theory the principle of the indeterminate sentence is not a new approach to the problem of crime and the criminal. As early as 1787 Dr. Benjamin Rush submitted a paper to a group, whp met at the home of Benjamin Franklin, proposing sevefal "radical" methods for the deterrance of crime, one of which advocated a break with the fixed sentence in favor of an indeterminate period of punishment proportioned to the progress of the prisoner. "Punishments should always be varied in degree accordipg to the temper of the criminal gr the progress of his reformation." Rush, An Inquiry Into the Efects of Public Punish ments $U_{\text {pon }}$ Criminals and Upon Society, Philadelphia, 1787 ; Teeters, The International Penal and Penitentiary Congress (rgro) and the Indeterminale Sentence, $39 \mathrm{~J}$. CRiM. 
the indeterminate sentence affords the systematic flexibility necessary to attain optimal results from the application of reformative treatment. ${ }^{7}$ For not only does it minimize the likelihood of excessive confinement, but it also provides an active and humane means of protecting society from the menace inherent in the release of persons with recidivistic tendencies before these tendencies have been modified. ${ }^{8}$

L., C. \& P.S. 618, 621, 622 (1949); Bennett, supro note 2, at 70. Additional evidence can be mustered to uphold the contention that Americans can claim the honor of having created the indeterminate sentence and adult reformatories, the purpose of the American measures being reformation and not retaliation through exaggerated punishment. The idea that an adult prisoner should be segregated from society until it is believed that he has reformed was realized for the first time, at least in the modified form of a minimum-maximum term rather than a strict definite term, following the opening of the Elmira, New York, institution in 1876 and by the passage of the Indeterminate Sentence Act of 1877 in the State of New York. In Europe the indefinite sentence was known as the "Elmira System." Teeters, supra at 622, 626; Tsheltrow-Bebutow, Indeterminate Sentence and Soviet Penal Las, r9 J. CRIM. L., C. \& P.S. 408 (1929); Timasheff, The Treatment of Persistent Offenders Outside of the United States, $30 \mathrm{~J}$. Crim. L., C. \& P.S. 455, 457, and n. 8 (1939). The Eighth International Penal \& Penitentiary Congress held in Washington, D. C., adopted a significant resolution approving the scientific principle of the true indeterminate sentence as applied to certain classes of offenders. Teeters, supra at 625, 627.

"See note I supra. Contra, consider the following: "The principle (of the indeterminate sentence) has been rejected by practical penology in its idealized form of the open-ended sentence, except for psychotic and feebleminded offenders. . . "Tappan, Sentences for Sex Criminals, 42 J. Crim. L., C. \& P.S. 332 (1951). The drafters of the Model Penal Code are committed to employment of the indefinite sentence with respect to young adult and adult offenders. Tappan, supra note 5, at 20, 22. However, it is interesting to note that the American Law Institute's Model Youth Correction Act of $1940 \mathrm{had}$ as an essential feature a true indetermimate sentence. Youngdahl, supra note 5, at 4 . For the reception afforded this act by the states, see Ellingston, supra note 2.

- Under the contemporary analysis, which seeks to reveal the true nature of the problem of developing a practical ineans for the curtailment of repeated crime, modern penologists recognize three basic classes of offenders: (I) those persons, primarily first offenders, who make a free and calculated choice of criminal conduct, but who otherwise possess the moral fiber and determination necessary to abstain from further misconduct; (2) those persons who either cannot or will not refrain from further criminal activity unaided, but who are susceptible to reformative treatment; (3) those persons who will not or cannot abstain from further criminal activity and whose tendencies cannot be modified by any known technique. This introduces the interesting question as to whether the scope of programs founded upon the authority of rehabilitation statutes, some of which are illustrated in note 2 supra should include an extension of the facilities and principles of rehabilitation to the first mentioned class of offenders and whether this type of offender should be among those individuals within the jurisdiction of a true indeterminate sentence, with no minimum or maximum term. By definition, a member of this class, who will be called a non-defective delinquent, is deemed to be capable of resisting the same pressures which originally impelled him 


\section{Sexual Psychopaths}

Perhaps the most extensive utilization of the indeterminate sentence is to be found in statutes, as enacted in twenty-two states and the Dis-

to offend society in such a manner that he was subject to criminal prosecution and conviction. It is felt that his behavior was conducted under the impulse of a choice of "free will," uninfluenced by mental or physical deficiencies, which would cause a repetition of such acts.

If it is assumed that this individual is not inclined toward recidivism, wherein does the danger lie to society, in once again having this person among it? Why should he not be released at once, since he is not classified as being dangerous to society, but rather as the victim of "accidental" circumstances which accumulated to cause him to break the legal barriers? The voice of restraint answers by suggesting that the maintenance of public support and sympathy with penal statutes and the deterrence of the offender and other persons in society might require some punishment to be imposed upon a non-defective delinquent. Otherwise the law might be veiewed as a feeble standard, to be evaded without fear of consequence. Society itself would be stimulating recidivistic tendencies toward repeated crime if the offender in question received no punishment whatsoever. Granted that the non-defective delinquent possesses the capabilities to becoine a law-abiding citizen, his desire to do so should be increased and fostered, rather than tempted.

To illustrate some of the offenders who might fall within the class of non-defective delinquents, there are defaulting bank presidents, draft dodgers, and persons who are convicted of a deliberate and substantial evasion of income taxes. In an article which treats of the problem of the selection of persons for probation, United States District Court Judge Alfred $D$. Barksdale writes that the above offenses ". . . occur to me as crimes for which substantial sentences are required." Barksdale, J., supra note I, at 6.

If agreement is reached that some period of confinement (punishment) is necessary, should it be attuned to the individual needs of the offender? That is, when it is determined that this individual has received sufficient incarceration to impress upon him a desire to maintain legal activities and a respect for the penal systen, should he be confined any longer? Revenge based on degree of crime is a discarded objective of enlightened penology, is it not? This article later examines and approves of the proposition, briefly stated, that the defective delinquent, who has reformed by virtue of the rehabilitation process, should be released from confinement at the moment at which this particular prisoner is best suited to return to society and when conditions in his counmunity are best adjusted for his reception. Once confinement has served its deterrent purpose, why should the non-defective remain imprisoned, while another prisoner, who was recidivistic and perhaps has committed a graver crime from the standpoint of consequences, will be released at the moment of his reformation? The non-defective delinquent should either be subject to release under an indeterminate sentence, as is suggested for the defective delinquent, or be eligible for parole and supervised freedom by receiving a sentence under, a statute which requires a maximum, but no minimum period of confinement. The second suggestion may be the better, since parole would be available to the prisoner at any proper time without the necessity of serving a mandatory minimum term. Furthermore, there is no need, for the protection of society, to subject this prisoner to a possible life sentence under an indeterminate sentence because by definition it is assumed that he is not recidivistic.

There seems to be more than a possibility that in a considerable number of cases it will be doubtful whether a prisoner has recidivistic criminal tèndencies or was driven 
trict of Columbia, dealing with offenders who are conventionally de-

to crime because of some defective mental or physical characteristics which apparently will cause him to repeat criminal actions. The precise accuracy of devices to determine the existence of criminal propensities and character defects is dubious, see note 3 supra, so that it may be impossible definitely to assert that one person should receive individualized treatment under both rehabilitation and individualized sentencing programs and that another should not. Both for the protection of society and of the offender, it would appear to be proper to extend the full scope of applicable modern penological programs to all prisoners. At least, each criminal should be eligible for rehabilitative treatment insofar as this can prevent an offender from coming out of confinement a more anti-social person than he was before his sentence began.

The remaining two classes, whose members possess recidivistic tendencies, comprisc the greatest single problem to penologists and jurists in the administration of criminal justice, for a mean statistical estimate would indicate that approximately twothirds of all prisoners have a record of one or more previous criminal convictions. For the year ending June $30,1956,63.5 \%$ of all prisoners committed to federal institutions under sentence of more than one year had one or more known previous commitments. U.S. DEP'T OF COMMERCE, STATISTTCAL ABSTRACT OF THE UNITED STATES: $1957,152$. Approximately thirty percent of such recidivists are deemed to be incorrigible. Tappan, objectives and Methods in Correction, Contemporary Correction 10 (Tappan ed. 1951). These groups are the prime target of modern theory and the object of the "more sensible goal" of prevention of repeated crime through individualized treatment designed to result in reformation of the offender.

Ala. Code tit. 15, $\$ \$ 34$ et seq. (Supp. 1953); Cat. Welfare \& Inst'ss Code $\$ \S 5125,5500$ et seq. (Supp. 1955); Colo. Rev. Stat. ANN. \$§ 39-19-1 et seq: (1953); D.C. CODE ANN. \$\$ 22-3503 et seq. (1951); FLA. STAT. ANN. \$\$ 917.12 et seq. (Supp. 1957); FLA. Stat. ANN. §§ 801.01 et seq. (Supp. 1957) (restricted to operation upon child molesters); ILL. REv. STAT. c. 108, $\$$ II2 (1955); ILL. ANN. STAT. c. 38, $\$ \$ 820.01$ et seq. (1955) (restricted to operation upon child molesterb); IND. ANN. STAT. $\$ \S 9-3401$ et seq. (1956); IOWA CODE $\$ \S 225$ A.r et seq. (Supp. 1955); Laws of Kansas c. I86 $\$ \S$ I et seq. (1953); MAss. ANN. Laws c. $123 \mathrm{~A}, \S \S$ i et seq. (Supp. 1957); Mich. Comp. LAWS \$§ 780-501 et seq. (Supp. 1956); Мich. Сомp. LAWs $\$ \S 750.10 a, 750.85,750.158,750.333,750.335 \mathrm{a}, 750.336,750.33^{8-.338 b}$, $750.520,767.61 \mathrm{a}$ (Supp. 1956); MiNN. STAT. ANN. \$§ 526.09 et seq., 246.43 et seq. (1953); Mo. ANN. STAT. \$§ 202.700 et seq. (1949); NEB. REv. STAT. \$§ 29-2gor et seq. (1956); N.H. REv. Stat. ANN. \$§ 173.1 et seq. (1955); N.Y. PEN. LAW §§ 243, 483-a, 690, 1944-a, 2188, 2189-a (Supp. 1957); N.Y. CORREC. LAW \$§ 212, 214 (Supp. 1957); OHIO REv. CODE ANN. $\$ \S 2947.24$ et seq. (Baldwin 1955); OrE. Rev. STAT. $\$ \S 137.111$ et seq. (1955) (restricted to operation upon child molesters); $\mathrm{P}_{\mathrm{A}}$. STAT. ANN. tit. 19, $\$ \S$ II66 et seq. (Supp. 1956); TENN. CODE ANn. \$§ 33-1301 et seq. (Supp. 1957); UTAH CODE ANN. §§ 77-49-1 et seq. (1953); WASH. Rev, CodE $\$ \S$ 71.06.010 et seq. (1953); W1s. STAT. \$ 959.15 (1955).

A Vermont statute which provides an indeterminate sentence for sexual psychopaths and defective delinquents will be considered infra in the discussion of defective delinquent laws.

A number of states have enacted statutes which ostensibly would afford indeterminate sentencing of sexual psychopaths. These acts are apparently seldom if ever used for this purpose, and, in as much as they primarily reflect mental health considerations, will not be included in this work. See, e.g., IDAHo CODE ANN. \$§ 66-317 et seq. (Supp. 
nominated "criminal sexual psychopaths."10 The sanction is typically invoked by either the county attorney or a responsible private individual acting upon a criminal charge, or conviction of a specific statutory sex crime, or personal knowledge of sexual aberration. If, after appropriate proceedings, ${ }^{11}$ the defendant is adjudged a sexual psychopath, he is, by court order, indefinitely confined in an appropriate institution for observation and treatment; $;^{12}$ and his release can be secured only when, in the opinion of the committing court or parole official, he has sufficiently recovered so as no longer presumptively to benefit from further treat-

1957).

Several states have excellent programs for treatment of sexual psychopaths on a determinate sentence basis. See, e.g., N.J. REv. STAT. §§ 2A:164-3 et seq. (1953).

For descriptions of the various sexual psychopath laws see $96 \mathrm{U}$. PA. L. REV. 872 (1948); I StAN. L. REv. 486 (I949); 25 IND. L.J. 186 (1950); 29 NEB. L. REV. 506 (1950); 2 WESTERN Res. L. Rev. 69 (1950); 60 YALE L.J. 346 (1951); 37 MAss. L.Q. 58 (April, 1952); 100 U. PA. L. REv. 727 (1952); 13 U. PITT. L. REV. 739 (1952); 33 NEB. L. REv. 475 (I954); 1954 WIs. L. REv. 324; 4 I IOWA L. REV. 523 (1956); 32 IND. L.J. 450 (1957).

${ }^{10}$ This class of persons may be defined generally as being composed of those persons who are afflicted with a mental infirmity, not amounting to insanity or feeble-mindedness, manifested by a crimimal propensity toward the commission of sexual offenses constituting a menace to the health and safety of self or others. To estimate the potential size of this class, consider the testimony of Dr. A. C. Kinsey, who draws on information accumulated during the first eleven years of his research project on human sex behavior. "... (F) roin the data we have obtained in our. study as a whole, we find that 95 percent of the population has in actuality engaged in sexual activities which are contrary to the law." Perhaps a significant lead to the solution of determining which pexsons fall within the definition of a criminal sexual psychopath is suggested by the following statement of Dr. Kinsey: "It is our finding, so far, that it is not more than 5 or to percent of the persons who are apprehended and convicted as sex offenders who are involved in behavior which is fundamentally different from that of a high proportion of the rest of the population." SUbCommitTeE on Sex Crimes, Preuiminary REPORT I05, 106 (Cal. 1949).

12 A petition is fled with the appropriate court seeking examination of the defendant for sexual psychopathy, and if good cause is shown the court will order the defendant examined by a specially constituted medical board. Should the report returned by the board indicate with reasonable certainty the presence of sexual psychopathy, the court will order a hearing to adjudicate this issue.

${ }^{19}$ Presumably in order to avert invalidation of these statutes upon ground of unconstitutionality, many states have specifically denominated their sexual psychopath acts as "civil" and/or placed them in a civil rather than a criminal code. A Michigan statute of 1937, the first of its kind, was included in the criminal code and declared unconstitutional in People v. Frontzak, 286 Mich. 51, 28I N.W. 534 (1938), discussed in comments, The Illinois Proposal to Confine Sexually Dangerous Persons, 40 J. CrIM. L., C. \& P.S. 186, I89, I90 (1949); Validity of Sex Offender Acts, 37 Mich. L. REV. 613, 62I (1939). The saving aspect of assigning a civil nature to these proceedings seems to lie in analogy to civil proceedings in insanity. See, for example, Minnesota ex rel. Pearson v. Probate Court, 309 U.S. 270 (1940). 
ment and no longer to constitute a menace to himself or to society. ${ }^{13}$ While it is probable that public hysteria over the incidence of outrageous sexual offenses rather than any appreciation of the penological significance of reformative treatment and the indeterminate sentence has been the catalyst in the enactment of a substantial portion of sexual psychopath statutes, ${ }^{14}$ it would be improper to evaluate such legislation in this light alone. Nor is lack of uniformity a valid basis for criticism, although it has been seized upon as such by some eminent authorities. ${ }^{15}$ Rather, any appraisal should be based upon a consideration of specific procedural and administrative provisions which measure the comity, or reflect the lack of it, between the penological justification for the indeterminate sentence and its statutory effect.

Implicit in the justification of the indeterminate sentence is an assumption that there exist the methods, facilities, and personnel uniquely adapted to the administration of such a program. ${ }^{16}$ At least California, ${ }^{17}$ the District of Columbia, ${ }^{18}$ and New Hampshire ${ }^{19}$ have existing special facilities for the treatment of sexual offenders. ${ }^{20}$ Otherwise, only the statutes of Florida, ${ }^{21}$ Maine, ${ }^{22}$ and Massachusetts ${ }^{23}$ provide in explicit terms for the construction of such facilities. ${ }^{24}$

${ }^{12}$ Upon release from commitment, the cured sexual psychopath may be subject to parol supervision or to any criminal charge or sentence suspended at the time of the institution of sexual psychopath proceedings. See note 9 supra.

14 Tappan, Sex Offender Laws and Their Administration, 14 FED. PRO. 32 (Sept. 1950).

${ }^{15}$ Ibid.

${ }^{18}$ That there is a paucity of these essential elements: ( 1 ) techniques of proven efficacy in determining the needs of each offender; (2) a sensible program of treatment specifically designed to achieve reformation; (3) qualified personnel and appropriate facilities adequate to administer such a program, see Tappan, Sentences for Sex Criminals, 42 J. CRIM. L., C. \& P.S. 332, 336. (1951).

${ }^{17}$ See note 9 supra.

${ }^{20}$ Ibid.

${ }^{90}$ SUBCOMMITTEE ON SEX CRIMES, op. cit. supra note 10, at $53,57,58$.

${ }^{32}$ See note 9 supra. "Ibid.

${ }^{32}$ Ibid.

${ }^{34}$ The Florida statute, unique in its completeness in this regard, provides for the creation of a research and treatment center to accomplish the following purposes: ". . . protection of society from physical harm, research into the causes of psychiatrical sex deviation, methods of preventing such deviation, methods for treating such deviation, methods for informing the community as to dealing with psychiatrical sexual deviation." FLA. 'TAT ANN. § 801.12 (1) (d) (Supp. 1957). Furthermore, Florida, in order to exploit fully the benefit of its diagnostic center, provides for transfer there of persons elsewhere confined, who would likely benefit in their efforts toward rehabilitation if they received treatment at the center. 
Since the purpose of the indeterminate sentence is fulfilled only if confinement terminates when sufficient reformation has been achieved, a program of redetermination of status would also appear to be necessary. ${ }^{25}$ The two methods most commonly adopted to conduce this end are: (I) the requirement that after a designated period following commitment the person confined or someone acting in his behalf be permitted to apply to an appropriate body for a redetermination of status; ${ }^{26}$ and (2) the requirement that the chief official of the institution in which the offender has been confined shall periodically ${ }^{27}$ cause his re-examination so long as incarceration shall continue, the report of which is to be submitted to the committing court or designated health authority. The statutes of twenty states ${ }^{28}$ include one or both of these requirements.

The greatest disparity between existing sexual psychopath legislation and the penological theory on which the indeterminate sentence is based would appear to lie in those statutory provisions affording a kind of dormancy to any criminal charge, conviction, or sentence upon which the psychopathic proceedings may have been predicated. 'Thus, a psychopath who has contributed to his reformative process and attained a minimum plateau of social conformity which would justify his release from confinement may, nevertheless, be subject to criminal prosecution and/or imprisonment for the acts which initially indicated corrective treatment. Confinement thus continued is purely retributive ${ }^{29}$ and a poor inducement, indeed, to reformation. If these provisions, however, merely indicate a lack of complete confidence in the methods of prognosticating social conformity, a minimum parole provision of consider-

${ }^{25}$ There is no apparent reason to abstain from statutory reference to a redetermination program if such abstention is to result in abuse of the purpose of reformative treatment by way of detention beyond the point of time contemplated by the statute.

${ }^{20}$ Ordinarily no subsequent application will: be heard within a stated period following the inost recent application. See note 9 supra.

${ }^{27}$ The inaximum interval of time so provided varies between the limit of six inonths in Pennsylvania and a period of two years in Oregon. The other eleven states which have adopted a provision of this general character specify a inaximun one year interval. See note 9 supra.

28 The following states have enacted statutes incorporating the requirements set forth in method (I): Alabama, California, Florida, Illinois, Indiana, Iowa, Massachusetts, Michigan, Minnesota, Missouri, Nebraska, New Hamphire, Pennsylvania, Tennessee, Wisconsin. The following states have adopted a provision of the general character of method (2) : Colorado, Florida, Indiana, Iowa, Massachusetts, Michigan, Minnesota, Missouri, New Hampshire, Oregon, Pennsylvania, Tennessee, Wisconsin. While eleven states have adopted both provisions, the District of Columbia, Kansas, New York, Ohio, Utah, and Washington have adopted neither. See note 9 supra.

"But see note I supra. 
able duration might, in the alternative, effectively allay any such apprehensions. It should be noted, however, that seven states ${ }^{30}$ provide that no person adjudged to be a sexual psychopath may thereafter be tried, sentenced, or confined upon offenses of which he originally stood charged or convicted.

What degree of manifestation of sexual aberration should be required to invoke the sex offender lawis? Since the probability of developing precise techniques for predicting the threat of an individual to society or to himself is exceedingly low, ${ }^{31}$ it would seem unfair to predicate determination of sexual psychopathy upon any manifestation other than some sort of criminal conviction. ${ }^{32}$ On the other hand, if the purpose of the sexual psychopath statute is to protect society, it would seem anomalous to "give" the offender one violation before taking steps to bring its remedial provisions into operation. Nevertheless, respect for individual rights coupled with the doubtful precision of any forecasting technique would seem to tip the balance in favor of requiring a criminal conviction as clear preliminary proof that an actual threat to society exists. ${ }^{33}$ In the District of Columbia, Iowa, Missouri, Nebraska, and New Hampshire, ${ }^{34}$ however, the minimum manifestation of sexual psychopathy necessary is a reasonable belief that it exists. And in Florida, Illinois, Indiana, Michigan, and Washington, ${ }^{35}$ a charge of a crime, ordinarily one of a specified sexual nature, is necessary to invoke the statute. The remaining statutes, however, become operative only upon persons convicted of or who plead guilty to some crime of a specified character.

Whether to include juveniles and persons charged with particularly

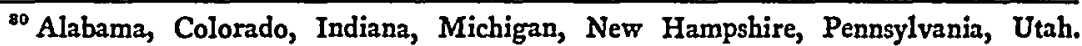
Contrast these statutes with that of Tennessee, where only after the criminal sentence has expired may imdeterminate confinement be imposed to continue until reformation is accomplished. See note 9 supra.

"See note 3 supra.

s2 ". . (A) society conceived, as ours is, for the protection of the individual must move with the greatest caution in conferring the authority to make commitments unless there has been some overt behavior of sufficiently significant dimensions to coinprise a major crime." Wechsler, Correctional Practices and the Law, 17 FED. Pro, 16, 18 (March 1953).

so It may be significant to note that the New York defective delinquent law, note 47 infra, originally provided for commitments "before or after conviction." In 1931 a prior conviction was made a statutory prerequisite to confinement. REIBLICH, AN Indeterminate Sentence Law for Defective Delinquents 19 (Md. Research Report No. 29, 1950).

at See note 9 supra.

as Ibid. 
heinous crimes within the purview of the sexual psychopath statutes also poses delicate problems. It is popular to be solicitous of the foibles of youth, and there are serious reservations concerning the effects of the operation of sex laws upon minors. ${ }^{38}$ On the other hand, if there is social justification for the operation of such statutes upon adults, the arguments against extending their coverage to juveniles are weakened by statistical studies revealing no appreciable predominance of adult over juvenile offenders in ratio of sex offenders to total offenders. ${ }^{37}$ The diffculty of obtaining a valid prognosis of criminal misconduct, however, is presumably much greater in the case of a juvenile, and perhaps it is upon this basis that eighteen states have omitted to provide juvenile jurisdiction under their sexual psychopath statutes. ${ }^{38}$

The exclusion in eight statutes of persons convicted of, or charged with, a heinous crime ${ }^{39}$ which would otherwise suffice to invoke statutory jurisdiction, however, would seem to stand on a different footing, for an analysis of the primary purpose of the indeterminate sentence-to provide a convenient basis for reformative treatment or, in the alternative, isolation of the offender so long as he is dangerous-does not disclose adequate basis for excepting the graver crimes. Indeed, the inference to be drawn from such exclusions is that they constitute either (I) a concession to the demands of an outraged public for retribution,,$^{40}$ (2) reaffirmance of the doctrine of prevention of crime through deterrence to be achieved by example, or (3) a destructive lack of confidence in the efficacy of reformative treatment.

so Tappan, Sex Offender Laws and Their Administration, 34 FED. PRO. 32, 35 (Sept. 1950). But see, Lukas, Crime Prevention: A Confusion in Goal, CoNTEMPORARY CoRRECTION 397, 403, 404 (Tappan ed. 3951), suggesting that crime prevention should entail dealing with people while they they are still young, before behavior patterns become fixed.

${ }^{87}$ Although sex crimes of violence are comparatively rare among juveniles, persons arrested on sex offense charges are younger on the average than are those arrested on all other grounds. SUbcomitTeE on SeX CRimes, Preliminary Report (Cal. I 949).

${ }^{28}$ Bowman, op. cit. infra note 46 , at 15, 21 . However, courts in the District of Columbia, Massachusetts, New Hampshire, Nebraska and Wisconsin may apply the sexual psychopath law to juveniles. See note 9 suppa.

${ }^{28}$ California (death sentence); District of Columbia (rape or assault with intent to rape); Florida (charge of a capital offense); Indiana (murder, manslaughter, sape of a female under 12); Minnesota (sodomy); Ohio (murder in first degree when inercy is not recommended); Pennsylvania (rape); Wisconsin (homicide or attempted homicide). See note 9 supra.

"Upon the perils of attempting combination of reformative treatment with retribution, see G. B. Shaw, The CRIME OF IMprISONMENT 26 (1946). 
Although not bearing precisely upon the implementation of the preventive theory under consideration, two statutory provisions merit comment. One of these, adopted by nine states, ${ }^{41}$ specifies a maximum period during which the evaluation of a subject prior to the adjudication of his status as a sexual psychopath must be made. This reflects an understandable inclination to eliminate a possible source of abuse, although the upper limit should not operate unduly to restrict inquiry. The second provision, which has been enacted in four states ${ }^{42}$ and the District of Columbia, limits the evidentiary use of the medical examining board's report to the psychopath proceedings; and Iowa and Missouri ${ }^{43}$ have gone so far as to provide that although the examining physicians may testify, their report is not admissible as evidence in any hearing. Some provision of this latter sort appears advisable, in as much as it might tend to conduce freer and more cooperative discussion on the part of the criminal subject and, in turn, a more accurate evaluation. It would also remove a possible source of constitutional objection on the ground of self-incrimination. ${ }^{44}$

It is conceded that contrary to popular belief, sex offenders are not inclined to recidivism, are considered excellent parole risks, ${ }^{45}$ and do not constitute a major percentage of prison population. ${ }^{48}$ It is important, however, to recognize that a criminal statute touching on any class of offenders and embodying the penological concept of protection of society through use of the indeterminate sentence and reformative treatment represents progress.

\section{Defective Delinquents}

Perhaps an even more graphic recognition of the theory of crime prevention through reformative treatment than the sexual psychopath enactments is the adoption, by ten states, ${ }^{47}$ of defective delinquent

${ }^{11}$ California, Massachusetts, Minnesota, New York, Oregon, Pennsylvania, Utah, Washington, Wisconsin. See note 9 supra.

"Florida, Indiana, Michigan, and Oregon. See note 9 supra.

is Ibid.

"See The Illinois Proposal to Confine Sexually Dangerous Persons, 40 J. CRIM. L., C. \& P.S. 186, 193-195 (1949).

${ }^{45}$ Tappan, Some Myths About the Sex Offender, 19 FED. Pro. 7-9 (June 1955).

16 Of 421,959 total arrests made during the period 1945-1950 in San Francisco, 12,681 were for charges of sex offenses. Bow (Cal. Judiciary Subcominittee on Sex Research, 1952).

"Cal. Welfare \& Inst'ns Code \$ 5600 et seq.; Cal. Welfare \& Inst'Ns Code $\S 7050$ et seq. (Supp. 1955); ConN. GEN. STAT. \$§ 1579d, 2791 et seq. (Supp. 1955); ME. Rev. Stat. ANN. c. 28, § I et seq. (1954); MD. ANN. Code art. 31B, 
statutes. ${ }^{48}$ Largely unhindered by the public hysteria impinging upon the.passage of much of the sex legislation and operative without regard to sexual aberration, these laws, although fewer in number, generally transcend the sexual psychopath statutes in approaching the goal of a broader application of reformative treatment under the indeterminate sentence. ${ }^{49}$ A valid observation has been made, however, to the effect that few defective delinquent statutes authorize segregation of many persons who could not have been segregated in institutions for the insane or feeble-minded under pre-existing laws. ${ }^{50}$ Moreover, since most defective delinquent as well as sexual psychopath laws are inoperative in the absence of some mental deficiency, the extent to which they are effective in preventing repeated crime is subject to question. A comparative analysis of specific defective delinquent provisions, nevertheless, discloses considerable achievement.

New York, the pioneer in the field of defective delinquent statutes, has, with its centers at Napanoch and Albion for the treatment of male and female defectives, respectively, provided an example worthy of emulation. ${ }^{51}$ The Maine enactment authorizes its representative on the

§ I et seq. (Supp. 1957); Mass. ANN. Laws c. 123, § I, I13 et seq. (1952); N.Y. Correc. LaW $\$ \S 430-449$, 450 et seq.; Pa. Stat. Ann. tit. 61, § 541-1 et seq. (Supp. 1957); ACTS AND Resolves of RHOde IsLand, c. 1852, § 1 et seq. (1947); Public ACTs of Vermont, $\$ 439$ et seq. (I951); PUBLIC ACTS OF VerMont, $\$ 422$ (1955); WASH. REV. CODE $\$ \$ 71.06 .010,71.06 .150$ et seq. (1951).

The Maryland statute will be discussed separately infra.

For description of some of the older defective delinquent laws see Robinson, Institutions for Defective Delinquents, 24 J. CRIM. L., C. \& P.S. 352 (1933); Papurt, The Classification of Defective Delinquents, 26 J. CRIM. L., C. \& P.S. 421 (1935); Gordon and Harris, An Investigation and Critique of the Defective Delinquent Statute in Massachusetts, 30 B.U.L. REv. 459 (1950).

4" These statutes ordinarily impose an indeterminate sentence upon a person afflicted by a mental deficiency, not amounting to insanity, when such person manifests a propensity to indulge in criminal activity and has thereby become a menace to himself or to society.

${ }^{10}$ Whereas sexually motivated offenders are the sole target of the sexual psychopath statutes, such offenders are but a fraction of those persons ostensibly included within the broader jurisdiction of the defective delinquent laws. Whereas sex offenders represent a relatively small percentage of the total criminal population, one survey has indicated that most of the more serious offenses are committed by mental defectives "over one sixth of the inmates convicted of killing and over one fourth of the inmates convicted of a sex offense were mental defectives." Rerilick, op. cit. supra note 33, at 3; note 46 supra.

${ }^{80}$ WAITE, op. cit. supra note 1 , at 121 .

${ }^{61}$ In Connecticut and New York, broader application of the indeterminate sentence as well as more effective use of treatment facilities are obtained by provisions authorizing 
Tri-State Facilities Authority of Maine, New Hampshire, and Vermont to plan for the construction of an institution for defective delinquents, while Connecticut, Massachusetts, and Pennsylvania have provided a separate facility for such persons. ${ }^{62}$

Only Massachusetts and New York have been moved to underline the serious responsibility of procuring the release of inmates when achievement of the power of minimal social conformity has been realized by providing for mandatory redetermination of status at a maximum time interval..$^{53}$ The New York statute further specifies that defective delinquent status may be reviewed upon petition for habeas corpus, while the statutes of Connecticut and Rhode Island provide that any person confined as a defective delinquent, or other person acting in his behalf, may petition for a hearing for re-determination of status. ${ }^{54}$

Among the more salutary aspects of existing defective delinquent laws is the fact that a high percentage of jurisdictions provides that confinement under defective delinquent statutes shall extinguish the original and pending criminal proceedings. Exemplary are the laws of Connecticut, Massachusetts, New York, and Washington. ${ }^{65}$ A reasonable construction of the Maine and Rhode Island acts would produce a similar effect, in as much as the officials in charge of the defective delinquent division, and the resident psychiatrist in the case of Maine, possess full control and authority over the discharge of such inmates. ${ }^{60}$

The extent to which recidivistic tendencies must be overtly manifested before the defective delinquent statutes may be applied varies. Five states ${ }^{57}$ require a criminal conviction, Massachusetts a criminal charge, and Maine a mere arrest on a criminal charge. ${ }^{58}$ An action under the California and Washington laws need only be predicated upon a petition filed by any one of several persons who presumably have informed impressions of the defendant. ${ }^{58}$

transfer from other state institutions into the department for defective delinquents. See note 47 supra.

${ }^{83}$ See note 47 suppra.

${ }^{88}$ The maximum time interval is three years in Massachusetts and two years in New

York. See note 47 supra.

so The remaining states, however, have created no similar express right of redetermination. See note 47 supra.

${ }^{58}$ These laws provide in effect that a finding of defective delinquency shall operate

to dismiss pending criminal proceedings. See note 47 supra.

${ }^{B 6}$ See note 47 supra.

${ }^{87}$ Connecticut, New York, Pennsylvania, Rhode Island, and Vermont. Ibid.

${ }^{83}$ See note 47 suppra.

${ }^{80} 1$ lbid. 
It is encouraging to note that of the states under consideration, only Massachusetts exempts from the operation of its law persons who possess delinquent personalities and who have been charged or convicted of specific crimes which otherwise would apparently suffice to invoke the statute, ${ }^{60}$ the remaining states thus emphasizing the reformative potential of the indeterminate sentence. ${ }^{61}$ Moreover, an appreciably higher percentage of defective delinquent statutes than sexual psychopath laws, provide for juvenile jurisdiction. ${ }^{62}$ Of particular interest in this regard are the enactments of California and Washington, which apply only to juveniles. ${ }^{63}$

A notable disparity exists in restrictions upon the time which may be consumed in evaluation of the delinquent. New York, evidently concerned with the freshness of the psychiatric examination, as well as unreasonable delay incident thereto, has provided that such examination must have been completed not more than sixty days prior to the order of commitment and that its preparation must not have consumed more than sixty days. ${ }^{\circ 4}$ Vermont-requires, perhaps wisely, that the time consumed in observation and examination for preparation of a report of status as a defective delinquent shall not exceed that deemed "necessary."05 Only Calffornia and Pennsylvania have made no provision in this regard, while the statutes of the remaining states provide that the period of observation shall not exceed an arbitrary time limit. ${ }^{68}$ It is disappointing to note that none of the defective delinquent statutes under consideration has adverted to the aspect of self-incrimination arising from evidentiary use of information gained in psychiatric examination. ${ }^{87}$

The Maryland defective delinquent statute should be particularly noted not only because it affords jurisdiction broader than that of other

\footnotetext{
- The Massachusetts exception, however, pertains only to persons convicted of first degree murder. Ibid.

${ }^{-1}$ In New York, however, lateral transfer into Napanoch of offenders confined elsewhere and who would benefit thereby is permitted, except as to those sentenced for murder in the first degree. N.Y. CoRREC. LAW $\S 439$.

'The exceptions are Maine, Rhode Island, and Vermont. By way of compromise, the statutes of Massachusetts and Pennsylvania are applicable to persons over the age of fifteen, while the Connecticut and New York laws afford jurisdiction over persons above sixteen years of age. See note 47 supra.

"See note 47 supra.

- Ibid.

${ }^{a}$ Ibid.

${ }^{\circ}$ Maine and Rhode Island, 30 days; Massachusetts, 35 days; Washington, 90 days; Connecticut, 6 months. See note 47 supra.

"r See note 44 supra.
} 
enactments bearing a similar designation, ${ }^{68}$ but because it has been an exemplary subject of an essential element in the fair administration of such laws, informed and aggressive legislative supervision. Illustrative of this superintendency is the legislative response to a recent case in which the Court of Appeals imposed an unreasonable construction upon the right of a confined defective delinquent to appeal from the denial of his petition for a writ of habeas corpus. ${ }^{80}$ In the legislative session next following this decision, an amendment to the habeas corpus statute was passed which clearly eliminated the possibility of another similar construction of the defective delinquent law. ${ }^{70}$ The original legislative committee report ${ }^{71}$ upon this law, furthermore, evinces an understanding of the purpose and significance of indeterminate sentencing and manifests recognition of the magnitude of the statutory power and of legislative responsibility to ensure against its abuse:

The primary purpose of such legislation is to protect society from this segnent of the criminal population who probably will again commit crimes if released on the expiration of a fixed sentence; and thus they should be detained and specially treated unless and until cured. A secondary purpose is more effectively and humanely to handle them, which aids in the cure, where possible. $^{72}$

Moreover, the broad Maryland definition of the term "defective delinquent" illustrates that state's near attainment of the desired goal:

... [A]n individual who, by the demonstration of persistent aggravated anti-social or criminal behavior, evidences a propensity toward criminal activity, and who is found to have either such intellectual deficiency or emotional unbalance, or both, as to clearly demonstrate an actual danger to society. ... . ${ }^{78}$ (Emphasis added.)

${ }^{\text {OB }}$ See note 73 infra.

${ }^{\circ 0}$ McElroy v. Director of Patuxent Institution, 211 Md. 385, 127 A.2d 380 (1956), where the court held that the petitioner, confined as a result of a defective delinquent proceeding predicated upon a criminal conviction was not confined as the "result of a prosecution for a criminal offense" and therefore was not entitled under the habeas corpus law to appeal from denial of his petition for the writ.

${ }^{70}$ MD. ANN. CODE art. 42, § 7 (Supp. 1957).

${ }^{72}$ ReIBLich, op. cit. supra note 33 .

72 Id. at X.

${ }^{78}$ MD. ANN. Code art. $3 \mathrm{rB}, \S 5$ (Supp. 1957), Dr. Morris J. Carpas is cited in LEwIs, op. cit. supra note 2 , at 72 , on the proposition that ". . too much stress has 
Thus, it would appear that the effect of this statute is not confined to those cases involving mental deficiency, nor is it overly concerned with the incidence of sex offenses. Rather, it applies to all those persons whom available inethods of prognostication indicate are recidivistic. Apparently, any potential chronic miscreants could be found to be in sufficient emotional imbalance so as to justify invoking the jurisdiction of the statute.

Upon careful consideration of meritorious provisions in similar enactments in other states, ${ }^{74}$ the Maryland legislative committee successfully urged the passage of many provisions necessary to ensure the protection of individual rights and an enlightened reformative process. The facilities at the Patuxent Institution, including a diagnostic center, at Jessups, Maryland, were created expressly for the custody. and treatment of defective delinquents. ${ }^{75}$ Jurisdiction of the Maryland act extends only to those who have been convicted of an offense falling within one of two specified classes of crimes, with no limitations resulting from the heinous nature of the offense or the severity of sentence. Furthermore, not only may an inmate petition for redetermination of his status with permissive maximum frequency, but he shall otherwise be re-examined at least once each year.

The juvenile jurisdiction of the Maryland law is limited, however, in that it shall not affect any case arising in a juvenile court unless the judge thereof shall have waived jurisdiction. ${ }^{76}$ And although the legislative committee considered carefully the anomaly of submitting a reformed delinquent to additional confinement in expiation of the original criminal conviction, ${ }^{77}$ it, nonetheless, recommended, and the statute requires, that the committing court retain the power to achieve this effect. Further, this act does not proscribe evidentiary usage of information gained in psychiatric examination.

been laid in the intellectual sphere and that little or no attention has been given to the emotional and volitional sphere in our treatment of the offender." Note that the definition of the subject of the Maryland law does not fail to protect against emotional or psychopathic delinquents of "normal" or even "high I.Q." intellectual ability; rather the definition includes mental deficiency as well as emotional disorder. REIBLICH, op. cit. suppra note 33 , at 11 .

"REIRLICH, op. cit. supra note 33 , at 10-12.

${ }^{78}$ These facilities may be made available to a transferee from another state institution so long as such person will be benefited and until his criminal sentence expires.

${ }^{76} \mathrm{MD}$. ANN. CODE art. 26, $\& 52$ (1951), provides that the Judge of the Juvenile Court shall have exclusive jurisdiction concerning any child who is delinquent or feeble-minded.

${ }^{77}$ ReIBLICH, op. cit. suppra note 33 , at 11 . 


\section{Conclusion}

Writing in 1943 , Dr. John B. Waite said:

Taken all together, these various statutes do no more than touch the edges of the difficulty. "Insane" persons may be confined for the sake of public safety. Persons dangerous to health may be confined. But men who have been punished as much as their committed crimes deserve cannot, under existing laws, be confined merely because it is evident that if released they will offend ägain:78

Since that date, the list of statutes referred to has grown to a more imposing size, and the resulting accretion of enactments ostensibly has done much to fill the void to which Dr. Waite adverted. Each of these statutes, to a varying degree, manifests the incorporation of sound penological theory, for each is unrelated to the heinousness of any crime involved, in so far as the maximum duration of the sentence it affords is concerned; each proposes its own method of achieving a common goal-the protection of society from repeated crime through reformative treatment, or, in the alternative, segregation of the offender so long as he is dangerous.

It has been said that this use of the indeterminate sentence is unrealistic and impractical. ${ }^{79}$ Indeed, many of the statutes to which reference has been made are in fact virtually inoperative. ${ }^{80}$ It should be noted, however, that there exist only two main causes for this condition: ${ }^{81}$ (I) the failure adequately to define the person who shall be subject to the particular law; and (2) apprehension on the part of many jurists of the grave injustices which inevitably would follow its reckless application. Although the former impediment poses no great problem, the latter is not susceptible of any easy solution. It would

${ }^{78}$ WAITE, op. cit. supra note $\mathrm{I}$, at 59,60 .

${ }^{70}$ See note 7 supra.

${ }^{80}$ E.g., Massachusetts, Michigan, New Hampshire, Vermont, Washington, Wisconson. REIBLICH, op. cit. supra note 33, chart; Tappan, Sex Offender Laws and Their Administration, 14 FED. PRO. 32, 37 (Sept. 1950). But see DePartment of CorRECTION, ThIRTIETH REPORT 20-25, 51, 87 (Maryland 1956) for reports marking the first full fiscal year, 1955-1956, the Patuxent Institution has been in operation. During the year eighteen men who had been sentenced to, and received in, other institutions were transferred to Patuxent on wholly indeterminate sentences. At the end of the fiscal year there were almost 100 inmates who were in some stage of being considered for such commitment by the courts of the state.

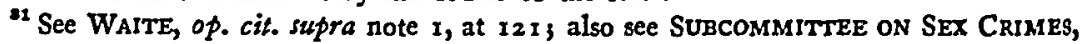
Preliminary Report 47 (Cal. r949). 
seem, however, that this area of statutory law is no different from others which have grown through continuous acceptance or adaptation of specific provisions to eliminate such imperfections as appear. It is, nonetheless, clear that zealous legislative supervision will be necessary to prevent minor imperfections from evolving into grave injustices. Much of the suspicion and criticism of the Maryland defective delinquent law by jurists of that state has been eliminated by the continuous surveillance of the General Assembly. ${ }^{82}$

It is highly possible that the type of legislative and judicial attitudes evinced in Maryland are essential to general acceptance and utilization of the existing statutes employing the indeterminate sentence in conjunction with reformative treatment. Given such an attitude, there appears to be no reason why this method should not be more fully developed, ${ }^{83}$ since, if applied with due diligence and conscience, indeterminate sentence laws can aid significantly in the solution of the vexing problem of repeated crime.

"The Maryland ". . . General Assembly, very properly, is keeping a close eye upon the operation of the act because of the new fields in which it operates and particularly because of the indeterminate sentence which is involved. It is encouraging, however, that in the last session of the Legislature of this year, there was no real attempt to repeal the law, although some amendments of the statute were enacted dealing with specific situations which had developed after the original statute had been passed. These amendments, in general, were helpful and constructive. . . . The press has also been sympathetic to and understanding of the objectives of the law and the problems connected with the establishment and running of the institution.

"It is too early as yet for the institution to have shown what can be done in the successful treatment of persons committed to it on an indeterminate sentence where there is hope for their cure. Of course, the law has a vital negative function-to keep incarcerated those persons found to be acute menaces to society and for whom there is no hope of rehabilitation. The prevention of the crimes which such persons would almost inevitably commit if they were released after the expiration of a fixed sentence is a fact not susceptible of proof, although I believe that there is no doubt whatsoever in the minds of psychiatrists, psychologists and other persons familiar with the situation, that many such crimes have been and will be prevented through the operation of the law." Letter from Reuben Oppenheimer, Judge, Supreme Bench of Baltimore City to the Duke Law Journal, Dec. 4, 1957, on file in Duke Law Library.

${ }^{88}$ Reflect on this observation: "Twenty-five years from now, every institution ought to owe its existence solely to the fact that it cares for a special group and has a special task to perform." Robinson, Penológy in the United States 321 (1923). 